\title{
Analysis of the Quality of Harvested Rainwater from the Top of Roofs in Diverse Materials at Low Temperature
}

\author{
Sakshi Gupta ${ }^{* *}$, Deepak Khare' and Nitin Mishra ${ }^{2}$ \\ 'Department of WRD \& M, IIT, Haridwar Highway, Roorkee - 247667, Uttarakhand India; \\ sakshilibran@gmail.com_kharefwt@gmail.com \\ 2Department of Civil Engineering, GEU, Clement Town, Dehradun - 248002, Uttarakhand, India; \\ nitinuag@gmail.com
}

\begin{abstract}
Objectives: The main objective behind this experimentation is to find the suitability of roof-top harvested rainwater with respect to its quality and to know about any changes that may occur in the parameters of the stored water and are essential to know before using it as potable water and to know about the different storage methodologies. The present study attempts to analyze the condition of rainwater harvested from the roof-tops so as to use that water as a source of drinking water. Methods/ Statistical Analysis: Rain water quality is an important factor which governs its suitability for potable use. But due to a rapid boost in the development particularly industries the rainwater trait is depreciating. For carrying out this study the rainwater was collected from the top of roofs and has been analyzed for a sanguine span to figure out its trait in consonance with the parameters for the potable water as given in Indian Standards on reserving for future with regard to time. The rainfall was collected from the dual contrasting locations from the concerned area under study i.e., Indian Institute of Technology, Roorkee campus, India based on the material of downpipe, surroundings of roof material and deviating levels of pollutants in atmosphere owing to the traffic load of the area and was stored under different materials to analyze for its quality through different quality tests on the various physical and chemical parameters. Findings: The experiment will result into finding of an appropriate approach regarding efficient roof-top rainwater harvesting and also the correct technique for the stashing of the rainfall gathered as well as to throw light on the aspects of temperature and material amidst time. Applications/Improvement: The similar experimentation can be carried out at other places as well with more locations for more diversity in the results attributing to the surroundings etc. to get a clearer and precise view about the roof-top harvested rainwater quality.
\end{abstract}

Keywords: Microbiological Quality, Polyethylene Container, Potable Water, Rainwater Quality, Roof-top

\section{Introduction}

Rainwater is often negotiated as a secured origin for drinking water and is used utmost in urban as well as in rural sector in most of the developing countries of the world. In various parts of India due to insufficient sources of freshwater rainwater is collected and stored for use during dry spells round the year. The curiosity to know about the quality of such water sources has initiated the present study. Fresh water sources are getting curbed day by day owing to the expeditious urbanization. The awareness for safe water use among the masses

${ }^{*}$ Author for correspondence 
has evoked an increment as well as an extra requirement for fresh water $\frac{1,2}{2}$. As per estimation healthy of around 1200 million folks is on a verge of danger which can lead to a final thrill of around 15 million adolescents every year. The first form of water in the nature's hydrologic cycle of water is rain supervened by the other minor sources of water like ground water, surface water present in form of lakes and rivers but unfortunately with the passing time this first and major form is being neglected irrespective of the truth that it is the one contributing to all the other sources of water. The art of collecting rainfall involves formation of water hoarding structures and in figuring out the real value of it so that it can be used there itself where it falls.

Reaping of rainwater is becoming essential in order to handle the extreme crisis of fresh and pure water in larger parts of the country. One of the premium ways of reaping rainwater in downtown areas is by using the rooftops as the catchment as they are not as contaminated as any other rain water harvesting catchment can be but in case of a barren spell or if roofs are found to have muck or mud and having any other unwanted contaminants then there are possibilities that the harvested water can be polluted 3 . In the recent few decades' collection of rainwater through roof-tops has been observed to be emerging very fast due to extreme lack of fresh water resulting due to rapid development globally. This work focuses to the greatest extent on the trait of water collected from rooftops and the individual elements having an impact on the trait as well. This trait generally comes out to be clashing from the range of parameters as given in Indian Standards in contempt of the stability that rainwater is the flawless form of water as per the way of its occurrence. At times massive metals and various fragments of contaminants due to pollution exist as well owing to the varying roof stuff and ambience ${ }^{4}$. The quality of harvested water after rainfall largely gambles on the layout and construction of the surface of catchment, maintenance as well as cleaning of the full mechanism and at the end the purification and remedial measures which are needed ahead its consumption ${ }^{5}$. In this ongoing study main relevance is laid on the aspect of collecting ways, storing, materials used for storing as well as microbiological quality and most critically the consideration for initiating a first flush past its use as a drinking water source ${ }^{6,7}$. It is also fundamental to figure out the alterations which might show up in the trait of the harvested water while it is kept to be used during barren spells.

\section{Study Area}

The expanse of study taken here is renowned Indian Institute of Technology, Roorkee in Uttarakhand. This ordinance has been ranked as the best institute in the world in technology as well as plays an important lead in contributing to all spheres of technological development. The city falls to be in the district of Haridwar concluded by the planar and a great range of Himalayas confining it in North as well as East. The Ganges canal flows along the city originating from north and going towards South dividing the city on the $58^{\text {th }}$ National highway between Delhi-Dehradun. It is also having the privilege to have the renowned Roorkee Cantonment and the Bengal sapper's headquarters since $18^{\text {th }}$ century. The city can be located on the map at $29.87^{\circ} \mathrm{N} 77.88^{\circ} \mathrm{E}$ with a middling rise of 268 meters and at 172 kilometers from New Delhi touching the Himalayan foothills between the great rivers Ganges and Yamuna.

\section{Sampling Stations and Sample Collection}

The choice for the regions for the collection of rainfall has been fixed as per the closeness to the stretches of having immense loads of traffic, their ambience and varying planes of pollution. Placed on this principle twain sites were selected in reach of the dorm itself a girl's hostel, Sarojini Bhawan which happens to be confined by trees and is also distant from any clutch of automobile pollution and the farther one on the outlying periphery of the institute, in close immediacy with laden loads of pollution caused by traffic in the atmosphere. The rainfall was collected from the top of the roofs in a singled-out act of rainfall only by using drain pipes coming to the ground from roofs using vessels under them and lastly was stored in different materials for storage owing to the struggle in first explicit assortment of rainwater ${ }^{-}$.

\section{Methodology and Data Presentation}

The rainfall assorted from the tops of the roof was kept at room temperature/low temperature in two diverse objects the borosilicate glass and polyethylene one. The speculation has been lugged out at a layoff of a peculiar 
time every month starting from September till February to analyze its trait in congruity with the details as listed in IS 10500: 2012 for drinking water parameters like acidity, turbidity, hardness, $\mathrm{pH}$, dissolved solids, alkalinity, chloride, total dissolved solids and specific conductivity. It was also taken care while collection that the rainwater was to be collected in the specific action of rainfall itself. The specific conductivity and $\mathrm{pH}$ have been found out by the help of digital data processors. The very first measurement was done within first hour of storage of collected rainfall at approximately $11 \mathrm{AM}$ and all the examination was recorded for that related time for every set. The distinctive guidelines for figuring out the trait of collected rainfall were analyzed by the help of stipulated chemical hand packs for water testing. In order to determine the amount of total dissolved solids present product of a constant 0.65 and value of specific conductivity has been taken. The microbiological quality of water was even examined at a stipulated pace of four weeks. The crucial forethought while testing was not to sum up fresh water to the reserved water all along the stash $\operatorname{span}^{9}$. In order to bypass the rise of algae during the span of reserving water it becomes compelling to save it from direct sunlight $t^{10}$. The distinct range of all the quality parameters is listed as in Tables 1 and 2.

\section{Results and Discussions}

In the beginning a slight turbidity has been observed in all the samples in debt to the remains of the debris in the reserved water which could not get remove in the first flush but later on it was found to be settling as a sediment during the span of storage and thereby producing the shifts in the range of turbidity and happens to be in consonance with the standard guidelines $s^{11,12}$.

The parameter which came out to be constant during the thorough reservation extent was Acidity and is straight away linked to the $\mathrm{pH}$ and turn out to be in the limits of standard guidelines. Also from this current analysis it can be wrapped up that the water quality in relation to the $\mathrm{pH}$ is far good in a borosilicate material as to that in a polyethylene. The range of hardness varied between $20 \mathrm{mg} / \mathrm{l}$ to $75 \mathrm{mg} / \mathrm{l}$ and is as per the standard guidelines without provoking any toxic effect on human health. As per the standards the value of Alkalinity up to $400 \mathrm{mg} / \mathrm{l}$ is ordinarily expressed as safe for drinking water and in current analysis it appeared to be in between $20 \mathrm{mg} / \mathrm{l}$ to $200 \mathrm{mg} / \mathrm{l}$ hence safe. Dissolved Oxygen has been found to be waffling in all the settings implementing the fluctuation with temperature, though from the aspect of human health it only passes taste to water and no detrimental

Table 1. Range of parameters in different materials at low temperature

\begin{tabular}{|c|c|c|c|c|c|c|c|c|c|c|}
\hline \multicolumn{11}{|c|}{ LOW TEMPERATURE DATA G.P HOSTEL } \\
\hline \multirow[t]{2}{*}{ PARAMETERS } & \multicolumn{2}{|c|}{$25 / 9 / 2015$} & \multicolumn{2}{|c|}{$1 / 11 / 2015$} & \multicolumn{2}{|c|}{$1 / 12 / 2015$} & \multicolumn{2}{|c|}{$2 / 1 / 2016$} & \multicolumn{2}{|c|}{$5 / 2 / 2016$} \\
\hline & PLASTIC & GLASS & PLASTIC & GLASS & PLASTIC & GLASS & PLASTIC & GLASS & PLASTIC & GLASS \\
\hline TURBIDITY & 1 & 1 & 0 & 0 & 0 & 0 & 0 & 0 & 0 & 0 \\
\hline ACIDITY & 10 & 10 & 10 & 10 & 10 & 10 & 10 & 10 & 10 & 10 \\
\hline PH & 6.5 & 6.5 & 5.5 & 7.5 & 5.5 & 7 & 5.5 & 7 & 5.5 & 7 \\
\hline HARDNESS & 30 & 30 & 16 & 14 & 24 & 22 & 20 & 20 & 20 & 20 \\
\hline ALKALINITY & 50 & 50 & 20 & 20 & 20 & 20 & 20 & 20 & 20 & 20 \\
\hline CHLORIDE & 30 & 30 & 10 & 10 & 10 & 10 & 10 & 10 & 10 & 10 \\
\hline $\begin{array}{l}\text { DISSOLVED } \\
\text { OXYGEN }\end{array}$ & 7.15 & 7.15 & 6.15 & 1.95 & 1.95 & 1.3 & 3.9 & 1.95 & 3.9 & 2.6 \\
\hline $\begin{array}{l}\text { SPECIFIC } \\
\text { CONDUCTIVITY }\end{array}$ & 5 & 5 & 4 & 4 & 4 & 3 & 4 & 3 & 4 & 3 \\
\hline TDS & 32.5 & 32.5 & 26 & 26 & 26 & 19.5 & 26 & 19.5 & 26 & 19.5 \\
\hline $\begin{array}{l}\text { MICROBIO- } \\
\text { LOGICAL } \\
\text { QUALITY }\end{array}$ & $\mathrm{P}$ & $\mathrm{P}$ & $\mathrm{P}$ & $\mathrm{P}$ & $\mathrm{P}$ & $\mathrm{P}$ & $\mathrm{N}$ & $\mathrm{N}$ & $\mathrm{N}$ & $\mathrm{N}$ \\
\hline
\end{tabular}


Table 2. Range of parameters in different materials at low temperature

\begin{tabular}{|c|c|c|c|c|c|c|c|c|c|c|}
\hline \multicolumn{11}{|c|}{ LOW TEMPERATURE SAROJINI BHAWAN } \\
\hline \multirow[t]{2}{*}{ PARAMETERS } & \multicolumn{2}{|c|}{$25 / 9 / 2015$} & \multicolumn{2}{|c|}{$1 / 11 / 2015$} & \multicolumn{2}{|c|}{$1 / 12 / 2015$} & \multicolumn{2}{|c|}{$2 / 1 / 2016$} & \multicolumn{2}{|c|}{$5 / 2 / 2016$} \\
\hline & PLASTIC & GLASS & PLASTIC & GLASS & PLASTIC & GLASS & PLASTIC & GLASS & PLASTIC & GLASS \\
\hline TURBIDITY & 5 & 0 & 0 & 0 & 0 & 0 & 0 & 0 & 0 & 0 \\
\hline ACIDITY & 10 & 10 & 10 & 10 & 10 & 10 & 10 & 10 & 10 & 10 \\
\hline PH & 6 & 5.5 & 5.5 & 5.5 & 5.5 & 5.5 & 5.5 & 5.5 & 5.5 & 7 \\
\hline HARDNESS & 40 & 40 & 30 & 40 & 24 & 18 & 16 & 20 & 20 & 16 \\
\hline ALKALINITY & 40 & 40 & 30 & 30 & 30 & 30 & 30 & 30 & 30 & 30 \\
\hline CHLORIDE & 20 & 20 & 20 & 20 & 20 & 20 & 20 & 20 & 20 & 20 \\
\hline $\begin{array}{l}\text { DISSOLVED } \\
\text { OXYGEN }\end{array}$ & 5.2 & 5.2 & 4.55 & 4.55 & 9.1 & 9.1 & 1.95 & 3.25 & 7.8 & 1.95 \\
\hline $\begin{array}{l}\text { SPECIFIC } \\
\text { CONDUCTIVITY }\end{array}$ & 5 & 5 & 4 & 4 & 4 & 16 & 5 & 6 & 4 & 4 \\
\hline TDS & 32.5 & 32.5 & 26 & 26 & 26 & 104 & 32.5 & 39 & 26 & 26 \\
\hline $\begin{array}{l}\text { MICROBIO- } \\
\text { LOGICAL } \\
\text { QUALITY }\end{array}$ & $\mathrm{P}$ & $\mathrm{P}$ & $\mathrm{P}$ & $\mathrm{P}$ & $\mathrm{P}$ & $\mathrm{P}$ & $\mathrm{N}$ & $\mathrm{N}$ & $\mathrm{N}$ & $\mathrm{N}$ \\
\hline
\end{tabular}

effects. The Chloride parameter came out to be perfect as well in this analysis.

Specific conductivity for rainwater usually varies between (10-20) micro Siemens/ $\mathrm{cm}$ and below 200 micro Siemens/ $\mathrm{cm}$ it is considered to be of good quality, also specific conductivity and Total Dissolved Solids for water are also straight away related to each other and a value of $500 \mathrm{mg} / \mathrm{l}$ is considered safe for drinking. Here as well these values are under the specified limits. In case of microbiological quality if a provision is maintained not to sum up any fresh water to the harvested rainwater it upgrades with time. In this study in the beginning the results came out to be positive hinting at the unfavorable conditions for using the reserved water as a drinking water but with advancing time owing to the improving quality the tests came out to be negative.

\section{Conclusion}

Drinking water needs to be determinately devoid of organic matter, minerals and any other substance which may root up any unfavorable effects on the consumer's health on using for a sustained time. Also it can be derived that the aspect of water enriches with time if no fresh water is computed to the reaped water and desirable care is implemented while collecting rainfall and its storage. Talking about the best material to be used for storage as per the current analysis borosilicate glass shows up to be a material surpassing the later for microbiological quality as well as a general criterion for drinking water at low heat climate if quality of rainwater harvested from the top of roofs needs to be uphold for an enduring span.

\section{References}

1. Meera V, Ahammed MM. Water quality of rooftop rainwater harvesting systems: A review. Journal of Water Supply: Research and Technology-AQUA. 2006 Jun 1;55(4):257-68.

2. Nzewi EU, Sarikonda S, Lee EJ. Monitoring of roof-harvested rainwater quality. Proceedings of the 2011 World Environmental and Water Resources Congress; 2011 May 22-26, Palm Springs: California; 2011.

3. ThomasPR, GreeneGR. Rainwater quality from different roof catchments. Water Science \& Technology. 1993; 28(3-5): 291-9

4. Yaziz MI, Gunting H, Sapari N, Ghazali AW. Variations in rainwater quality from roof catchments. Water Research. 1989 Jun 30; 23(6):761-5. 
5. Michaelides G, Young R. Provisions in design and maintenance to protect water quality from roof catchments. International Journal of Environmental Studies. 1985 Jun $1 ; 25(1-2): 1$.

6. Kurukulasuriya M. Effective application of first flush device to improve rainwater quality. 9th International Rainwater Catchment Systems Conference - Rainwater Catchment: An Answer to the Water Scarcity of the Next Millennium: Petrolina, Brazil; 1999 Jul.

7. Lye DJ. Rooftop runoff as a source of contamination: A review. Science of the Total Environment. 2009 Oct 15; 407(21):5429-34.

8. Kitamura K, Kita I, Takeuchi A. The effect of storage location on collected rainwater quality [Internet].
Available from: http://eng.warwick.ac.uk/ircsa/pdf/9th/ 12_14.pdf.

9. Martinson B, Thomas T. Improving water quality by design. 11th International Conference on Rainwater Catchment Systems, Mexico City; 2003 Aug.

10. Klein B, Bullerman M. Qualitative aspects of rainwater use in the Federal Republic of Germany. Fourth International Conference on Rainwater Cistern Systems, Manila; 1989 Aug. p. 2-4).

11. IS 10500: 2012 [Internet]. [cited 2012 May]. Available from: https://law.resource.org/pub/in/bis/S06/.

12. WHO Guidelines [Internet]. [cited 2013 Sep 13]. Available from: http://www.who.int/water_sanitation_health/dwq/. 